\title{
Model Probabilitas Penggunaan Moda Kereta Komuter Bagi Pekerja Ulang-Alik Sidoarjo- Surabaya di Kecamatan Waru
}

\author{
Sovianita Natasha dan Ketut Dewi Martha Erli Handayeni \\ Departemen Perencanaan Wilayah dan Kota, Fakultas Arsitektur Desain dan Perencanaan \\ Institut Teknologi Sepuluh Nopember (ITS) 60111 Indonesia \\ e-mail: erli.martha@urplan.its.ac.id
}

\begin{abstract}
Abstrak-Kecamatan Waru merupakan wilayah suburban Kota Surabaya yang terkena ekspansi berupa perluasan permukiman, terutama bagi pekerja. Pergerakan ulang-alik dari Kecamatan Waru ke Kota Surabaya yang dilakukan oleh pekerja dengan menggunakan kendaraan pribadi, terutama sepeda motor menyebabkan terjadinya kemacetan. Kereta Komuter Surabaya-Porong (SuPor) yang disediakan guna meminimalisir kemacetan masih belum digunakan secara efektif dan rendah peminat. Hal ini dapat terlihat dari load factor Kereta Komuter SuPor hanya 13\% dan Stasiun Waru menjadi stasiun dengan jumlah penumpang terendah dibandingkan stasiun lainnya di Kota Surabaya dan Kabupaten Sidoarjo. Penelitian ini bertujuan untuk menyusun model probabilitas penggunaan moda kereta komuter bagi pekerja ulang-alik Sidoarjo-Surabaya di Kecamatan Waru dengan menggunakan analisis regresi logit biner. Hasil studi menunjukan bahwa probabilitas penggunaan moda kereta komuter dipengaruhi secara signifikan oleh variabel biaya, waktu, dan kemudahan mencapai tujuan.
\end{abstract}

Kata Kunci-Model Probabilitas, Kereta Komuter, Pekerja Ulang-Alik.

\section{PENDAHULUAN}

S URABAYA sebagai pusat dari Surabaya Metropolitan Area (SMA) mempunyai daya tarik yang luar biasa sebagai tujuan beraktivitas. Kota Surabaya menjadi pusat kegiatan sosial dan ekonomi yang mampu menarik para pekerja. Kepadatan dan keterbatasan lahan di Kota Surabaya mendorong terjadinya ekspansi atau perkembangan ke arah pinggiran kota, salah satunya Kabupaten Sidoarjo. Kabupaten Sidoarjo menyediakan lahan alternatif untuk menampung perluasan kawasan permukiman dan industrir[1]. Sebagai wilayah perbatasan antara Kota Surabaya dan Kabupaten Sidoarjo, Kecamatan Waru menerima imbas yang besar dari terjadinya ekspansi[2].

Kecamatan Waru merupakan wilayah prospek pengembangan tinggi dan kawasan strategis yang memiliki fungsi utama untuk permukiman, industri, dan perdagangan. Setiap tahunnya terjadi peningkatan jumlah penduduk dan jumlah pendatang di Kecamatan Waru. 34,27\% dari luas kawasan terbangun di sekitar kawasan transit didominasi oleh perumahan kepadatan tinggi dan sedang[3]. Hal ini menunjukkan bahwa peningkatan jumlah penduduk disebabkan oleh faktor tempat tinggal. Masyarakat lebih memilih untuk tinggal di pinggiran kota dimana harga lebih rendah dan bekerja di perkotaan dengan upah yang tinggi, akibatnya terjadi pergerakan yang tinggi dari pinggiran ke pusat kota[4].

Dalam melakukan pergerakan, 80\% masyarakat di Kecamatan Waru menggunakan kendaraan pribadi untuk beraktivitas dengan rincian $69 \%$ menggunakan sepeda motor dan 21\% menggunakan mobil[5]. Pergerakan penduduk ini menyebabkan terjadinya kemacetan, terutama di Kota Surabaya yang dapat terlihat pada Jalan Ahmad Yani pada pukul 07.00 dan 16.00 yang disebabkan oleh tingginya aktivitas dan pergerakan pelaku perjalanan[6]. Pada tahun 2016, Degree of Saturation (DS) di Jalan Ahmad Yani sebesar 1,8 yang berarti tingkat pelayanan jalan Ahmad Yani berada pada titik terendah, yakni Level of Service (LOS) F. Pergerakan ulang-alik dari pinggiran kota ke Jalan Ahmad Yani sebesar 1.481.344 unit/hari menjadi kontribusi besar terhadap terjadinya kemacetan di Surabaya[2].

Kemacetan dapat diminamilisir jika pelaku pergerakan beralih dari kendaraan pribadi ke angkutan umum, salah satunya Kereta Komuter Surabaya-Porong (SuPor). Dalam sehari, Kereta Komuter SuPor melakukan perjalan sebanyak 3 kali pulang-pergi pada pagi, siang, dan sore hari. Namun, penggunaannya masih minim peminat. Hal ini terlihat dari load factor kereta komuter hanya 13\%. Frekuensi penumpang yang rutin menggunakan kereta komuter diketahui hanya $26 \%$, sisanya didominasi oleh penumpang yang hanya 1 hingga 2 kali melakukan perjalanan dengan kereta komuter. Stasiun Waru merupakan stasiun keberangkatan dengan jumlah penumpang kereta komuter paling kecil dibanding 6 stasiun lainnya[3].

Penggunaan kendaraan pribadi dalam jumlah besar sebagai moda pergerakan para pekerja membawa dampak yang buruk terhadap terjadinya kemacetan. Kereta komuter yang melayani perjalanan pada jam puncak, ternyata belum mampu mengakomodasi kebutuhan pekerja ulang-alik. Oleh karena itu, perlu kajian untuk mengetahui faktor-faktor apa yang memengaruhi kemungkinan penggunaan kereta komuter bagi pekerja ulang-alik guna mengurangi kemacetan

\section{METODE PENELITIAN}

\section{A. Pendekatan dan Jenis Penelitian}

Pendekatan yang digunakan dalam penelitian ini adalah pendekatan positivistik, yakni pendekatan yang meyakini bahwa realitas atau fenomena dapat dijlasifikasikan dan relatif tetap, konkrit, teramati, terukur, dan terdapat hubungan sebab akibat. Sedangkan, jenis penelitian ini merupakan penelitian deskriptif yang berfokus pada gejala atau fenomena yang kemudian dianalisis dengan menggunakan teori yang objektif yang bertujuan untuk memberikan gambaran terhadap suatu fenomena secara detail, sistematis, faktual, dan akurat[7]. 


\section{B. Variabel Penelitian}

Terdapat 16 variabel pada penelitian ini yang terbagi menjadi 3 indikator, yakni indikator karakteristik pelaku perjalanan, perjalanan, dan pelayanan moda dapat dilihat pada Tabel 1.

Tabel 1.

Indikator dan Variabel Penelitian

\begin{tabular}{cl}
\hline \hline \multicolumn{1}{c}{ Indikator } & \multicolumn{1}{c}{ Variabel } \\
\hline Karakteristik Pelaku Perjalanan & Kepemilikan kendaraan pribadi \\
& Jenis kelamin \\
& Usia \\
& Pekerjaan \\
& Pendapatan \\
Kemampuan berkendara & Lokasi tinggal \\
Karakteristik Perjalanan & Tujuan perjalanan \\
& Jarak perjalanan \\
& Waktu \\
& Biaya \\
& Kemudahan mencapai tujuan \\
& Keandalan \\
& Kenyamanan \\
& Keamanan \\
& Parkir \\
\hline \hline
\end{tabular}

\section{Metode Sampling}

Metode sampling yang digunakan pada penelitian ini adalah simple random sampling. Dengan jumlah populasi yang tidak diketahui, penentuan jumlah sampel ditentukan dengan Formula Lemeshow dan berpedoman pada teori Roscoe.

Sampel pada penelitian ini adalah 106 sampel dengan rincian 76 responden pekerja ulang-alik yang menggunakan sepeda motor dan 30 responden pekerja ulang-alik yang menggunakan kereta komuter. Dalam memilih responden terdapat beberapa kriteria yang harus dipenuhi, yaitu: 1) Pekerja yang tinggalnya terjangkau radius pelayanan Stasiun Waru sejauh 4,8 km, yakni Kelurahan Medaeng, Pepelegi, Waru, Kureksari, Ngingas, Tropodo, Wadungsari, Berbek, Kepuh Kiriman, Wedoro, Janti, Kedungrejo, dan Bungurasih; 2) Pekerja yang bekerja di Kota Surabaya; dan 3) Pekerja yang menggunakan kendaraan pribadi (sepeda motor) atau kereta komuter untuk melakukan perjalanan ulang-alik.

\section{Teknik Analisis Data}

Dalam menyusun model probabilitas penggunaan moda kereta komuter, terdapat tiga sasaran yang harus dilakukan. Sasaran pertama adalah mengidentifikasi karakteristik pekerja dan pola pergerakan bagi pekerja ulang-alik SidoarjoSurabaya di Kecamatan Waru dengan analisis statistik deskriptif. Input data adalah karakteristik pelaku perjalanan yang terdiri dari variabel jenis kelamin, usia, pekerjaan, pendapatan, kemampuan berkendara, dan kepemilikan kendaraan pribadi, serta karakteristik pola pergerakan yang terdiri dari variabel lokasi tinggal, tujuan perjalanan, dan jarak perjalanan. Output yang dihasilkan adalah tabel, grafik, deskripsi, dan peta karakteristik pekerja dan pola pergerakan pekerja ulang-alik Sidoarjo-Surabaya di Kecamatan Waru.

Sasaran kedua yakni menganalisis faktor-faktor yang memengaruhi penggunaan moda bagi pekerja ulang-alik Sidoarjo-Surabaya di Kecamatan Waru dan sasaran ketiga yakni memodelkan probabilitas penggunaan moda kereta komuter bagi pekerja ulang-alik Sidoarjo-Surabaya di Kecamatan Waru dianalisis dengan analisis regresi logit biner dengan bantuan software Statistic Package for Social Science (SPSS) versi 22. Input data sasaran kedua adalah karakteristik pelaku perjalanan yang terdiri dari variabel jenis kelamin, usia, pekerjaan, pendapatan, kemampuan berkendara, dan kepemilikan kendaraan pribadi; karakteristik pola pergerakan yang terdiri dari variabel lokasi tinggal, tujuan perjalanan, dan jarak perjalanan; serta karakteristik pelayanan moda yang terdiri dari variabel biaya, waktu, kemudahan mencapai tujuan, keandalan, kenyamanan, keamanan, dan parkir. Adapun persamaan model regresi sebagai berikut.

$$
\begin{aligned}
& \mathbf{Y}=\ln \frac{\mathbf{P}}{1-\mathbf{P}}=\boldsymbol{\beta}_{\mathbf{0}}+\boldsymbol{\beta}_{\mathbf{1}} \mathbf{X}_{\mathbf{1}}+\boldsymbol{\beta}_{\mathbf{2}} \mathbf{X}_{2}+\cdots+\boldsymbol{\beta}_{\mathbf{n}} \boldsymbol{\beta}_{\mathbf{n}} \\
& P=\frac{1}{1+e^{-(-\boldsymbol{\beta} \mathbf{0}+\boldsymbol{\beta} \mathbf{1 X 1}+\boldsymbol{\beta} \mathbf{2 X} 2+\ldots+\boldsymbol{\beta} \mathbf{n X n})}}
\end{aligned}
$$

Dimana:

In = Logaritma natural

$\mathrm{P} \quad=$ Peluang pengguna moda kereta komuter

$1-\mathrm{P}=$ Peluang pengguna moda kendaraan pribadi

$\beta_{0}=$ Konstanta

$\beta_{\mathrm{n}} \quad=$ Koefisien Variabel $\mathrm{X}$ ke $\mathrm{n}$

$\mathrm{X}_{\mathrm{n}} \quad=$ Variabel independen ke $\mathrm{n}$

Output yang dihasilkan berupa faktor-faktor yang secara signifikan memengaruhi penggunaan moda dan model probabilitas penggunaan moda kereta komuter bagi pekerja ulang-alik Sidoarjo-Surabaya di Kecamatan Waru.

\section{HASIL DAN DISKUSI}

A. Mengidentifikasi Karakteristik Pekerja dan Pola Pergerakan Bagi Pekerja Ulang-Alik Sidoarjo-Surabaya di Kecamatan Waru

Analisis ini bertujuan untuk mengetahui karakteristik pelaku perjalanan dan perjalanan pekerja ulang-alik SidoarjoSurabaya yang berdomisili di Kecamatan Waru. Responden pada analisis ini adalah 124 pekerja ulang-alik, baik yang menggunakan kendaraan pribadi (sepeda motor) maupun kereta komuter untuk bekerja. Adapun hasilnya sebagai berikut:

\section{1) Jenis Kelamin}

Jenis kelamin pekerja ulang-alik didominasi oleh perempuan dengan persentase 56\%, sedangkan laki-laki dengan persentase $44 \%$.

\section{2) Usia}

Usia pekerja ulang-alik didominasi oleh kelompok usia 2024 tahun dengan persentase $44 \%$.

3) Pekerjaan

Pekerjaan pekerja ulang-alik didominasi bekerja sebagai pegawai swasta dengan persentase $56 \%$.

\section{4) Pendapatan per Bulan}

Pendapatan pekerja ulang-alik didominasi pada rentang Rp 2.500.001-Rp 5.000.000 dengan persentase 41\%.

5) Kepemilikan Kendaraan Pribadi

Jumlah kendaraan pribadi yang dimiliki oleh pekerja ulang-alik didominasi sebanyak 1 buah kendaraan.

\section{6) Kemampuan Berkendara}

Pekerja ulang-alik didominasi oleh pekerja yang mampu berkendara dengan persentase $97 \%$.

\section{7) Lokasi Tinggal}

Pekerja ulang-alik didominasi oleh pekerja yang tinggal di Kelurahan Wedoro dengan persentase 25\%. 


\section{8) Tujuan Perjalanan}

Pekerja ulang-alik didominasi oleh pekerja dengan tujuan perjalanan ke Kelurahan Airlangga dengan persentase 10\%.

9) Jarak Perjalanan

Pekerja ulang-alik didominasi oleh pekerja dengan jarak perjalanan dari lokasi tinggal ke tujuan perjalanan sejauh 1417 kilometer $(\mathrm{km})$ dengan persentase $43 \%$.

B. Menganalisis Faktor-Faktor yang Memengaruhi Penggunaan Moda Bagi Pekerja Ulang-Alik SidoarjoSurabaya di Kecamatan Waru

Analisis ini bertujuan untuk mengetahui faktor-faktor yang memengaruhi pemilihan moda pekerja ulang-alik SidoarjoSurabaya di Kecamatan Waru. Responden pada analisis ini terdiri dari 33 pekerja yang sekarang menggunakan kendaraan pribadi (sepeda motor) dan dulunya menggunakan kereta komuter, serta 32 pekerja yang sekarang menggunakan kereta komuter dan dulunya menggunakan kendaraan pribadi (sepeda motor). Sehingga, didapatkan 65 data pelayanan moda kendaraan pribadi dan 65 data pelayanan moda kereta komuter untuk dianalisis menggunakan regresi logit biner pada SPSS.

Berikut adalah hasil identifikasi pergerakan dan pelayanan moda sepeda motor dan kereta komuter:

\section{1) Jarak Perjalanan}

Jarak perjalanan yang menggunakan sepeda motor didominasi 12,51-15,00 $\mathrm{km}$ dengan persentase $49 \%$ dan kereta komuter didominasi 15,01-17,50 km dengan persentase $32 \%$. Jarak perjalanan kereta komuter relatif sedang, tidak dekat dan tidak jauh. Berbeda dengan jarak perjalanan kendaraan pribadi yang beragam.

2) Waktu

Waktu yang dibutuhkan dari Stasiun Waru ke Stasiun Wonokromo \pm 15 menit, dari Stasiun Waru ke Stasiun Gubeng \pm 20 menit, dan dari Stasiun Waru ke Stasiun Surabaya Kota \pm 30 menit. Waktu perjalanan menggunakan sepeda motor didominasi 2,89-3,46 menit $/ \mathrm{km}$ dengan persentase $45 \%$ dan kereta komuter didominasi 2,31-2,88 menit/km dengan persentase $35 \%$.

3) Biaya

Tarif sekali naik kereta komuter adalah Rp 5.000,00. Biaya menggunakan sepeda motor didominasi Rp 615-Rp 994 per $\mathrm{km}$ dengan persentase $54 \%$ dan kereta komuter didominasi Rp 235-Rp 614 per km dengan persentase 49\%. Biaya yang dikeluarkan ketika menggunakan kereta komuter lebih rendah dibandingkan sepeda motor.

\section{4) Kemudahan Mencapai Tujuan}

Kemudahan mencapai tujuan sepeda motor didominasi oleh nilai sulit dengan persentase $86 \%$ dan kereta komuter didominasi oleh nilai mudah dengan persentase 64\%. Perjalanan menggunakan sepeda motor sering terhambat dikarenakan terjebak kemacetan terutama pada jam-jam puncak, yakni pagi hari dikala berangkat kerja dan sore hari dikala pulang kerja. Sementara, kereta komuter relatif lancar karena memiliki jalur sendiri, walaupun terkadang perjalanannya terhambat sebentar karena mendahulukan kereta lain yang lewat.

\section{5) Keandalan}

Keandalan sepeda motor didominasi oleh nilai buruk dengan persentase $58 \%$ dan kereta komuter didominasi oleh nilai baik dengan persentase $72 \%$. Pengguna sepeda motor seringkali tidak tepat waktu sampai tujuan karena terjebak kemacetan, waktu diperjalanan lebih lama dibandingkan yang diharapkan. Hal ini berimbas dengan waktu kedatangan ke lokasi kerja yang diluar harapan atau dengan kata lain tidak tepat waktu sesuai yang diharapkan. Berbeda dengan kereta komuter yang perjalanannya tidak mengalami hambatan, keterlambatan kedatangan jarang terjadi, jika mengalami keterlambatan tidak terlalu lama, hanya sekitar 5 menit, yang mana menurut pengguna kereta komuter hal tersebut masih dalam batas wajar dan tidak menganggu waktu sampai tujuan atau dengan kata lain tepat waktu.

\section{6) Kenyamanan}

Kenyamanan sepeda motor didominasi oleh nilai nyaman dengan persentase 53\% dan kereta komuter didominasi oleh nilai nyaman dengan persentase $63 \%$. Kondisi kendaraan kereta komuter baik dan kokoh dan tidak terlihat tua atau usang, bersih, serta terdapat beberapa fasilitas kenyamanan, salah satunya tempat duduk di gerbong kereta yang cukup nyaman disertai dengan tegakan tempat duduk. Begitupun dengan kondisi sepeda motor yang dinilai baik dan kokoh yang tidak mengganggu kenyamanan pengguna saat melakukan perjalanan.

\section{7) Keamanan}

Keamanan sepeda motor didominasi oleh nilai aman dengan persentase $63 \%$ dan kereta komuter didominasi oleh nilai aman dengan persentase $61 \%$. Tidak adanya safety belt bagi pengguna kereta komuter sebagai alat pelindung diri. Badan kereta kokoh dianggap mampu melindungi dan mencegah terjadinya benturan langsung jika terjadi kecelakaan.Begitupun dengan kondisi sepeda motor yang dinilai memiliki tingkat keamanan dan keselamatan dari kecelakaan yan dinilai aman, contohnya kendaraan pribadi memiliki helm sebagai alat pelindung diri yang dianggap mampu melindungi dan meminimalisir resiko cidera dan benturan kecelakaan.

\section{8) Parkir}

Parkir di lokasi kerja bagi pengguna sepeda motor didominasi oleh nilai memadai dengan persentase $78 \%$ dan di Stasiun Waru bagi pengguna kereta komuter didominasi oleh nilai memadai dengan persentase $76 \%$. Fasilitas parkir di lokasi kerja bagi pengguna sepeda motor adalah memadai dengan lahan yang cukup luas, dan lokasinya di dalam bangunan, sehingga mampu melindungi kendaraan dari terik matahari dan air hujan. Sementara, fasilitas parkir di Stasiun Waru terbatas dan tidak terlalu luas. Namun, sebagian besar menilai bahwa parkir di Stasiun Waru memadai karena pengguna kereta komuter tersebut menggunakan angkutan kota (lyn), jalan kaki, dan diantar untuk menuju Stasiun Waru yang mana tidak memanfaatkan fasilitas parkir. Sehingga menurut pengguna, dengan adanya fasilitas parkir tanpa memperhatikan kondisinya tetap bisa dinilai memadai.

\begin{tabular}{lcccc}
\multicolumn{5}{c}{ Tabel 2. } \\
Uji Wald \\
\hline \hline \multicolumn{1}{c}{ Variabel } & B & Wald & Sig & EXP \\
\hline Jenis Kelamin & 0,185 & 0,084 & 0,772 & 1,204 \\
Usia & 0,001 & 0,025 & 0,983 & 1,001 \\
Pekerjaan 1 & 1,288 & 1,367 & 0,346 & 3,62 \\
Pekerjaan 2 & 2,61 & 1,265 & 0,837 & 1,298 \\
Pekerjaan 3 & 3,18 & 0,880 & 0,718 & 1,374 \\
Pendapatan & 0,000 & 0,000 & 0,630 & 1,000 \\
Kepemilikan Kendaraan & 0,094 & 0,251 & 0,708 & 1,099 \\
Pribadi & & & & \\
Kemampuan Berkendara & 0,504 & 1,929 & 0,794 & 0,604 \\
Lokasi Tinggal & 0,396 & 0,244 & 0,105 & 1,485 \\
Tujuan Perjalanan & 0,076 & 0,195 & 0,698 & 1,078
\end{tabular}




\begin{tabular}{lcccc} 
Jarak Perjalanan & $-0,217$ & 0,103 & 0,034 & 0,805 \\
Waktu & $-2,014$ & 0,536 & 0,000 & 0,134 \\
Biaya & $-0,003$ & 0,001 & 0,010 & 0,997 \\
$\begin{array}{l}\text { Kemudahan Mencapai } \\
\text { Tujuan }\end{array}$ & 1,444 & 0,617 & 0,019 & 4,238 \\
Keandalan & 0,740 & 0,566 & 0,191 & 2,095 \\
Kenyamanan & 0,607 & 0,551 & 0,270 & 1,836 \\
Keamanan & $-0,730$ & 0,543 & 0,179 & 0,482 \\
Parkir & $-0,437$ & 0,680 & 0,521 & 0,646 \\
\hline \hline
\end{tabular}

Untuk mengetahui faktor-faktor berpengaruh dapat diketahui dengan melihat nilai $p$-value (sig) pada Uji Parsial atau Uji Wald yang dipeoleh dari hasil analisis SPSS. Variabel independen yang memiliki nilai p-value (sig) dibawah 0,1 merupakan variabel atau faktor yang dianggap berpengaruh secara signifikan terhadap pemilihan moda sebagai berikut.

Tabel 3.

Nilai Signifikansi Variabel Independen Pada Uji Wald

\begin{tabular}{lcc}
\hline \multicolumn{1}{c}{ Variabel } & Nilai Sig & Keterangan \\
\hline Jenis kelamin & 0,772 & Tidak signifikan \\
Usia & 0,983 & Tidak signifikan \\
Wiraswasta & 0,346 & Tidak signifikan \\
PNS & 0,837 & Tidak signifikan \\
Swasta & 0,718 & Tidak signifikan \\
Pendapatan & 0,630 & Tidak signifikan \\
Kepemilikan kendaraan & 0,708 & Tidak signifikan \\
pribadi & 0,794 & Tidak signifikan \\
Kemampuan berkendara & 0,105 & Tidak signifikan \\
Lokasi tinggal & 0,698 & Tidak signifikan \\
Tujuan perjalanan & 0,034 & Signifikan \\
Jarak perjalanan & 0,000 & Signifikan \\
Waktu & 0,010 & Signifikan \\
Biaya & 0,019 & Signifikan \\
Kemudahan mencapai tujuan & 0,191 & Tidak signifikan \\
Keandalan & 0,270 & Tidak signifikan \\
Kenyamanan & 0,179 & Tidak signifikan \\
Keamanan & 0,521 & Tidak signifikan \\
Parkir & & \\
\hline \hline
\end{tabular}

Dari 16 variabel independen, terdapat 4 variabel yang memiliki nilai $p$-value (sig) dibawah 0,1 , yakni variabel jarak perjalanan yang merupakan karakteristik pola pergerakan; waktu, biaya, dan kemudahan mencapai tujuan yang merupakan karakteristik pelayanan moda dianggap secara signifikan memengaruhi penggunaan moda bagi pekerja ulang-alik Sidoarjo-Surabaya di Kecamatan Waru. Sedangkan 12 variabel independen yang memiliki niali $p$ value (sig) diatas 0,1 , yakni variabel jenis kelamin, usia, pekerjaan yang terdiri dari wiraswasta, PNS, dan swasta, pendapatan, kepemilikan kendaraan pribadi, dan kemampuan berkendara yang merupakan variabel pada karakteristik pekerja; lokasi tinggal dan tujuan perjalanan yang merupakan karakteristik pola pergerakan; keandalan, kenyamanan, keamanan, dan parkir yang merupakan karakteristik pola pergerakan dianggap tidak signifika memengaruhi penggunaan moda.

\section{Memodelkan probabilitas penggunaan moda kereta komuter bagi pekerja ulang-alik Sidoarjo-Surabaya di Kecamatan Waru}

Sebelum menyusun suatu model regresi perlu dilakukan uji kesesuaian model untuk mengetahui kelayakan suatu model sebagai berikut.

Tabel 4.

Uji Kesesuaian Model Regresi

\begin{tabular}{|c|c|}
\hline $\begin{array}{l}\text { Uji Kesesuaian } \\
\text { Model }\end{array}$ & Keterangan \\
\hline $\begin{array}{l}\text { Estimasi } \\
\text { Parameter }\end{array}$ & $\begin{array}{l}\text { Nilai -2 Log likelihood pada tahap pertama adalah } \\
115.414 \text {, setelah dimasukan variabel independen, } \\
\text { nilainya menjadi } 104.617 \text { dengan mengalami } 6 \\
\text { kali iterasi. Sehingga, model regresi dianggap } \\
\text { telah mendapat nilai likelihood maksimal dan } \\
\text { model dinyatakan fit dengan data. }\end{array}$ \\
\hline Goodness of Fit & $\begin{array}{l}\text { Berdasarkan hasil SPSS diketahui bahwa nilai } p \text { - } \\
\text { value adalah 0,792 yang mana lebih besar dari 0,1. }\end{array}$ \\
\hline & $\begin{array}{l}\text { Sehingga Ho diterima dan model dianggap } \\
\text { mampu menjelaskan data observasi. }\end{array}$ \\
\hline Model Summary & $\begin{array}{l}\text { Berdasrkan hasil SPSS diketahui bahwa nilai } \mathrm{R} \\
\text { Square adalah } 0,5888 \text { yang berarti variabel } \\
\text { independen dapat menjelaskan variabel dependen } \\
\text { sebesar } 58,8 \% \text { dan } 41,2 \% \text { dijelaskan oleh variabel } \\
\text { lain }\end{array}$ \\
\hline $\begin{array}{l}\text { Ketetapan } \\
\text { Klasifikasi }\end{array}$ & $\begin{array}{l}\text { Berdasarkan hasil analisis, nilai Overall } \\
\text { Percentage adalah } 83,1 \% \text { yang berarti model } \\
\text { mampu memprediksi kejadian sesungguhnya } \\
\text { berdasarkan data observasi sebesar } 83,1 \% \text {. }\end{array}$ \\
\hline \multirow[t]{2}{*}{$\begin{array}{l}\text { Uji } \\
\text { Multikolinearitas }\end{array}$} & $\begin{array}{l}\text { Berdasarkan hasil analisis, tidak terdapat nilai } \\
\text { korelasi yang melebihi 0,5 pada persilangan } \\
\text { variabel satu dengan lainnya yang berarti tidak } \\
\text { terjadi gejala multikolinearitas antar variabel. }\end{array}$ \\
\hline & $\begin{array}{l}\text { Sehingga, semua variabel independen bisa } \\
\text { dimasukan tanpa perlu direduksi. }\end{array}$ \\
\hline \multirow[t]{2}{*}{ Overall Test } & $\begin{array}{l}\text { Berdasarkan hasil analisis SPSS diketahui bahwa } \\
\text { nilai } p \text { value (Sig) adalah } 0,000 \text { yang mana lebih } \\
\text { kecil dari } 0,1 \text {. }\end{array}$ \\
\hline & $\begin{array}{l}\text { Sehingga, variabel indenpenden diaggap } \\
\text { signifikan memengaruhi variabel dependen dan } \\
\text { memberikan pengaruh nyata terhadap model. }\end{array}$ \\
\hline Uji Wald & $\begin{array}{l}\text { Berdasarkan hasil analisis diketahui bahwa } 4 \text { dari } \\
16 \text { variabel memiliki nilai signifikansi }<0,1 \text {. }\end{array}$ \\
\hline
\end{tabular}

Model ini disusun berdasarkan nilai koefisien (B) pada variabel independen yang memiliki nilai sig atau $p$-value dibawah 0,1 pada Uji Wald yang telah dilakukan dengan analisis regresi logit biner. Berdasarkan Uji Wald terdapat 4 variabel independen yang memiliki nilai sig dibawah 0,1, yaitu jarak perjalanan, waktu, biaya, dan kemudahan mencapai tujuan.

Tabel 5.

Variabel Berpengaruh Pemilihan Moda

\begin{tabular}{ccc}
\hline \hline Variabel & Koefisien Variabel (B) & EXP (B) \\
\hline Jarak perjalanan (X9) & $-0,217$ & 0,805 \\
Waktu (X10) & $-2,014$ & 0,134 \\
Biaya (X11) & $-0,003$ & 0,997 \\
Kemudahan mencapai tujuan & 1,444 & 4,238 \\
(X12) & & \\
\hline \hline
\end{tabular}

Untuk variabel jarak perjalanan yang merupakan karakteristik perjalanan diketahui bahwa peningkatan jarak perjalanan sebesar $1 \mathrm{~km}$ akan menyebabkan penurunan probabilitas penggunaan moda kereta komuter sebesar 0,805 kali lebih rendah. 
Untuk variabel waktu yang merupakan karakteristik pelayanan moda diketahui bahwa peningkatan waktu 1 menit/km akan menyebabkan penurunan probabilitas penggunaan moda kereta komuter sebesar 0,134 kali lebih rendah. Untuk variabel biaya, diketahui bahwa peningkatan biaya sebesar $\mathrm{Rp} 1 / \mathrm{km}$ akan menyebabkan penurunan probabilitas penggunaan moda kereta komuter meningkat sebesar 0,997 kali lebih rendah. Untuk variabel kemudahan mencapai tujuan, jika tingkat kemudahan mencapai tujuan meningkat 1 tingkat menjadi “mudah”, maka probabilitas penggunaan moda kereta komuter akan meningkat sebesar 4,238 kali lebih tinggi.

Nilai Odd Ratio (EXP) yang paling tinggi adalah variabel kemudahan mencapai tujuan dengan 4,238 dan yang paling rendah adalah variabel waktu dengan 0,134. Dari nilai tersebut dapat diketahui bahwa dari keempat variabel tersebut yang paling tinggi pengaruhnya dalam meningkatkan probabilitas penggunaan moda kereta komuter adalah kemudahan mencapai tujuan dan yang paling rendah adalah waktu. Adapun model probabilitas penggunaan moda kereta komuter bagi pekerja ulang-alik Sidoarjo-Surabaya di Kecamatan Waru dapat dituliskan sebagai berikut.

Adapun model probabilitas penggunaan moda kereta komuter bagi pekerja ulang-alik Sidoarjo-Surabaya di Kecamatan Waru dapat dituliskan sebagai berikut.

$$
\begin{aligned}
& \text { In } \frac{P}{1-P}=8,004-0,217 X_{9}-2,014 X_{10}- \\
& 0,003 X_{11}+0,217 X_{9}+1,444 X_{12} \\
& \mathbf{P}=\frac{1}{1+e^{-(8,004-0,217 \times 9-2,014 \times 10-0,003 \times 11+1,444 \times 12)}} \\
& \text { Dimana: } \\
& \mathrm{P}=\text { Probabilitas penggunaan moda kereta komuter } \\
& \text { X9 = Jarak perjalanan } \\
& \mathrm{X} 10=\text { Waktu } \\
& \mathrm{X} 11 \text { = Biaya } \\
& \text { X12 = Kemudahan Mencapai Tujuan }
\end{aligned}
$$

Dari model tersebut diketahui bahwa nilai konstansa sebesar 8,004 merupakan selisih antara nilai konstan pengguna kereta komuter dan kendaraan pribadi berdasarkan 4 variabel yang signifikan dalam memengaruhi penggunaan moda, yakni jarak perjalanan (X9), waktu (X10), biaya (X11), dan kemudahan mencapai tujuan (X12). Nilai koefisien sebesar -0,217 merupakan selisih antara utilitas jarak perjalanan (X9) antara pengguna kereta komuter dan kendaraan pribadi. Nilai koefisien sebesar -2,014 merupakan merupakan selisih antara utilitas waktu (X10) antara pengguna kereta komuter dan kendaraan pribadi. Nilai koefisien sebesar -0,003 merupakan selisih antara utilitas biaya (X11) antara pengguna kereta komuter dan kendaraan pribadi. Nilai koefisien sebesar 1,444 merupakan selisih antara utilitas kemudahan mencapai tujuan (X12) antara pengguna kereta komuter dan kendaraan pribadi.

Pengaruh variabel terhadap probabilitas penggunaan moda kereta komuter dapat dilihat dengan menggunakan grafik sensitivitas.

\section{1) Variabel Biaya}

Simulasi sensitivitas variabel biaya dilakukan dengan mengubah nilai variabel biaya dari Rp 0 - Rp 1.000 km/jam dengan hasil sebagai berikut.

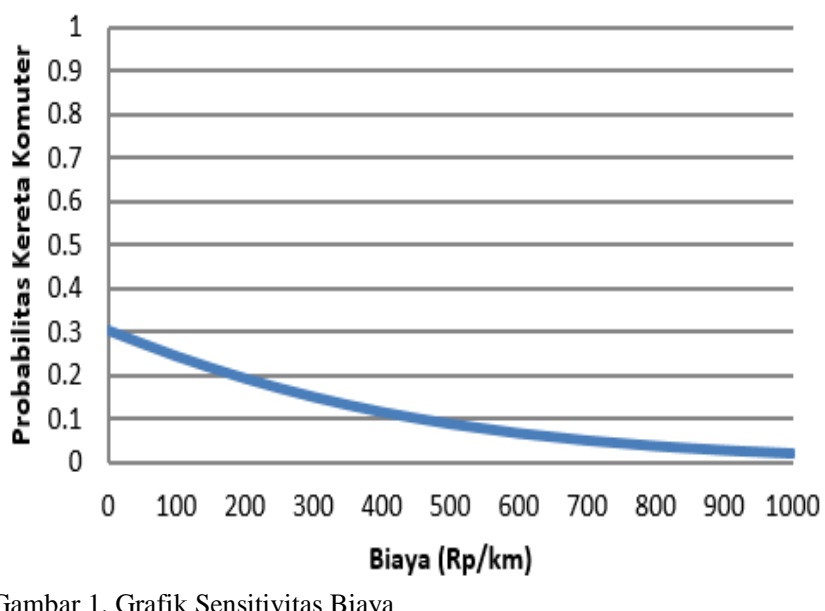

Berdasarkan grafik diatas dapat diketahui bahwa kemiringan garis menunjukan arah negatif yang berarti semakin rendah biaya yang dikeluarkan ketika menggunakan kereta komuter, probabilitas penggunaan moda kereta komuter akan meningkat, sedangkan semakin tinggi biaya yang dikeluarkan ketika menggunakan kereta komuter, probabilitas penggunaan moda kereta komuter akan menurun. Sehingga, untuk meningkatkan probabilitas penggunaan moda kereta komuter, hendaknya biaya kereta komuter lebih rendah dibandingkan dengan biaya perjalanan menggunakan sepeda motor.

2) Variabel Waktu

Simulasi sensitivitas variabel biaya dilakukan dengan mengubah nilai variabel waktu dari 0 menit $/ \mathrm{km}-4$ menit $/ \mathrm{km}$ dengan hasil sebagai berikut.

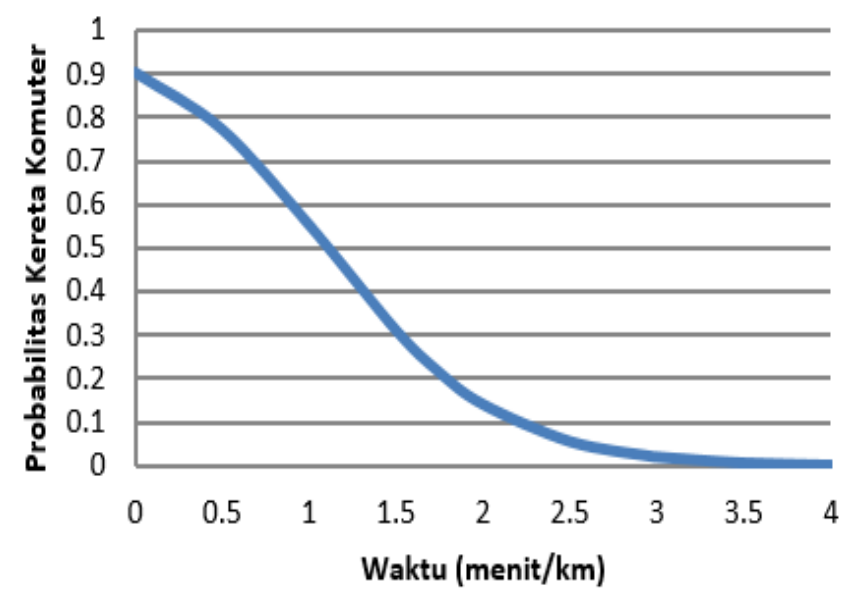

Gambar 2. Grafik Sensitivitas Waktu

Berdasarkan grafik diatas dapat diketahui bahwa kemiringan garis menunjukan arah negatif yang berarti semakin singkat waktu perjalanan yang dihabiskan dengan kereta komuter, probabilitas penggunaan moda kereta komuter akan meningkat, sedangkan semakin lama waktu perjalanan yang dihabiskan dengan kereta komuter, probabilitas penggunaan moda kereta komuter akan menurun. Sehingga, untuk meningkatkan probabilitas penggunaan moda kereta komuter, hendaknya waktu perjalanan menggunakan kereta komuter lebih dipersingkat dibandingkan dengan waktu perjalanan menggunakan sepeda motor. 


\section{KESIMPULAN}

Dari 16 variabel independen, terdapat 4 variabel yang secara signifikan memengaruhi penggunaan moda, yakni variabel jarak perjalanan, waktu, biaya, dan kemudahan mencapai tujuan.

Dari keempat variabel yang secara signifikan memengaruhi penggunaan moda, variabel kemudahan mencapai tujuan adalah variabel yang paling berpengaruh, sedangkan yang terendah pengaruhnya adalah waktu.

Probabilitas penggunaan moda kereta komuter dapat ditingkatkan dengan menaikan tingkat kemudahan mencapai tujuan, memperendah biaya, dan mempersingkat waktu perjalanan dengan kereta komuter.

\section{DAFTAR PUSTAKA}

[1] L. D. Rohmadiani and A. A. G. A. Ramayadnya, "Identifikasi keterkaitan hinterland dengan pusat kota," in Temu Ilmiah IPLBI , 2016, pp. E73-E80.
[2] M. Serlin, M. A. Serlin, and E. Umilia, "Faktor-faktor yang mempengaruhi masyarakat dalam memilih lokasi hunian peri urban Surabaya di Sidoarjo,” J. Tek. ITS, vol. 2, no. 2, pp. C143-C148, Sep. 2013.

[3] M. H. Isa, “Arahan pengembangan kawasan transit oriented development (TOD) dalam mendorong penggunaan kereta komuter koridor Surabaya-Sidoarjo,” Institut Teknologi Sepuluh Nopember, 2014.

[4] H. Bohman and D. Nilsson, "The impact of regional commuter trains on property values: Price segments and income,” J. Transp. Geogr., 2016.

[5] S. O. Rachmadita, “Arahan kebijakan modal shift kendaraan pribadi ke bus kota untuk pekerja ulang-alik Sidoarjo-Surabaya di Kecamatan Waru.,” Institut Teknologi Sepuluh Nopember, 2010.

[6] W. Boediningsih, "Dampak kepadatan lalu lintas terhadap Kota Surabaya,” J. Fak. Huk., vol. XX, no. 20, pp. 119-137, 2011.

[7] P. Priyono, Metode penelitian kuantitatif. Sidoarjo: Zifatama, 2016. 